Politik Ekonomik Kuram 2020, Cilt 4(1), 124-140

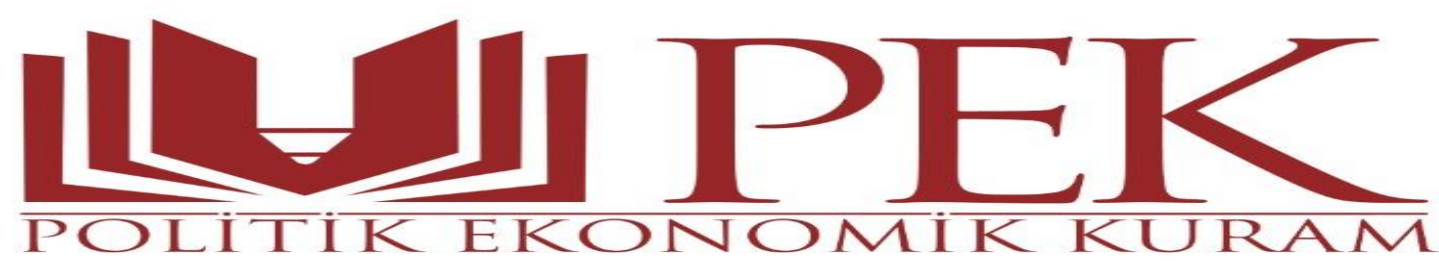

\title{
Covid-19’un Küresel Makroekonomik Etkileri ve Beklentiler
}

Emek Aslı CINEL ${ }^{1}$

Makale Bilgileri

Makale Geçmişi:

Makalenin Yüklendiği Tarih: 05.06.2020

Makalenin Kabul Edildiği Tarih: 18.06.2020

Anahtar Kelimeler: Covid-19, büyüme, dünya.

https://doi.org/10.30586/pek.748538

${ }^{1}$ Dr. Öğr. Üyesi, Giresun Üniversitesi, İktisadi ve İdari Bilimler Fakültesi. 
$\ddot{O} \mathbf{z}$

Bu çalışma Covid-19 krizinin endüstriler ve ülkeler üzerindeki ekonomik etkilerine odaklanmakta ve ekonomik faaliyetlerin etkilenebileceği ekonomik kanallar tartışılmaktadır. Çalışmada öncelikli olarak koronavirüsün daha önce görülen krizlerden hangi yönleriyle farklı olduğu araştırılmakta olup mevcut gelişmelere ve tahminlere rehberlik edebilecek veriler ortaya konulmaktadır. Çalışmada daha sonra bazı olası senaryolar ve bunların ekonomik beklentiler üzerindeki etkileri araştırılmakta, Covid-19'un potansiyel küresel ekonomik maliyetleri incelenmekte, yayılmasını önlemek için alınması gerekli olan önlemlere ve uygulanması gereken politikalara yer verilmektedir.

\title{
The Global Macroeconomic Impacts of Covid-19 and Expectations
}

\begin{abstract}
This study focuses on the economic effects of the Covid-19 crisis on industries and countries, and discusses the economic channels through which economic activities may be affected. In this study, first of all, the aspects of coronavirus are different from previous crises are investigated and data that can guide current developments and forecasts are presented. The study then explores some possible scenarios and their impact on economic prospects, examines the potential global economic costs of Covid-19 and measures to take and policies to prevent them from spreading.
\end{abstract}

Keywords: Covid-19, growth, world.

Jel Codes: I12, I15, I18. 


\section{Giriş}

Korona virüsü 2019 yılının aralık ayında Çin'in Wuhan eyaletinde başlamış olup tüm dünyaya hızla yayılmıştır. Bazı ülkeler bildirilen vakalara etkili bir biçimde muamele ederken yeni vakaların ne zaman ortaya çıkacağı henüz tam olarak bilinmemektedir. Her geçen gün Dünya Sağlık Örgütü daha fazla vaka rapor etmekte ve korona virüsün görülmeye başladığı yeni ülke sayısı hızla artmaktadır. Bugün her ne kadar Çin'de görülen vakalar zirveye ulaşsa da, zamanla düşüş eğilimine girmiştir. Bu durumun tam tersi trendler Avrupa ve Amerika'da görülmektedir. Halk sağlığı riski göz önüne alındığında, Dünya Sağlık Örgütü bu durumu pandemi olarak ilan etmiş bulunmaktadır. Güçlü bir biçimde birbirine bağlı ve bütünleşmiş bir yeryüzünde hastalığın etkileri ölümün de ötesine geçmiş durumdadır. $\mathrm{Bu}$ bağlamda, hükümetler beklenmedik durum planları hazırlamakta ve ekonomik çöküşü engellemek için yardım paketleri almaktadır.

Korona virüs sonrası Çin ekonomisinde ciddi anlamda kilitlenmeler ortaya çıkmış olup bu durum üretimde ve tüketimde azalmaya yol açmıştır. Genel olarak, küresel tedarik zincirlerinin işleyişi bozulmuş, dünyadaki tüm şirketler bu durumdan olumsuz yönde etkilenmiştir. Milyonlarca insan gelecekte işlerini kaybedebilecek duruma gelmiştir. Buna ilave olarak, her gün daha fazla şirketin kapanmasıyla ilgili endişe verici haberler ortaya çıkmaktadır. Tüketicilerin tüketim kalıpları değişmiş, küresel finans piyasalarında keskin düşüşler kaydedilmiş olup piyasalardaki oynaklık 2008 ve 2009 mali krizlerine benzer bir seyir izlemiştir. Uluslararası Para Fonu (IMF), 2020 yılına ait büyüme rakamlarına ait yeni tahminlerde bulunmuştur. Revize edilmiş tahminlerinde, IMF Çin'in büyümede \%0,4 yavaşlama sergileyeceğini belirtmiş olup küresel büyümede $\% 0,1$ azalmanın ortaya çıkacağını vurgulamıştır. Dolayısıyla, politika yapıcıların virüse ve etkilerine karşı uyumlu bir politika arayışı içine girmeleri acil ve zorunlu olmaktadır.

İkinci Dünya Savaşı sonrası dünyada ortalama durgunluk ve işsizlik oranı hızla artmıştır. Daha önce yaşanan krizlerle karşılaştırıldığında korana virüs salgını sonrası ortaya çıkan tablo oldukça farklıdır. Dünya eş zamanlı bir talep ve arz şokuyla karşı karşıyadır ve kaynaklar sınırlıdır. Genel olarak bu krizin potansiyel etkileri tarihte daha önce görülenden daha büyüktür. Çalışma Covid-19 krizinin endüstriler ve ülkeler üzerindeki ekonomik etkilerini araştırmaktadır. Krizin dünya genelinde ortaya çıkardığı ekonomik maliyetler incelenmekte ve uygulanması gereken ekonomi politikalarıyla, önerilere yer verilmektedir. 


\section{20. Yüzyılın Korkutucu Salgını: 1918 Küresel Gribi}

Pandemiye yönelik en kötü tahminlerden biri, 1918 ve 1919'da dünya genelinde 40 milyon insanı öldüren 1918 küresel gribine dayanmaktadır. 1918 yılında dünya genelinde ortaya çıkan grip dünya nüfusunun üçte birini enfekte etmiştir. Bugün benzer bir durum ortaya çıkar ve dünya çapında hızla yayılırsa, 80 milyondan daha fazla kişinin ölümüne yol açabilecektir. Ani ölümlere ek olarak, korona virüs salgını paniğe neden olup küresel ekonomi ve ticareti ciddi şekilde etkilemiştir. 1918-1919 döneminde görülen grip salgını tekrar ortaya çıkarsa 4 trilyon dolardan fazla ekonomik maliyete yol açabileceği tahmin edilmektedir (Crosby, 2003).

1918 yılında ortaya çıkan grip de korona virüs gibi farklı yaş gruplarını farklı şekilde etkilemekteydi. Ancak en ölümcül etkiler çocuklar ve yaşlılar üzerinde görülmekteydi. Savaş zamanı birçok ülkede hükümetlerin ölüm ve vaka sayılarını açıklamayı reddetmesi nedeniyle hastalığın yaygınlığı ve öldürücülüğünün boyutları tam olarak anlaşılamamıştır. Küresel çapta oluşan bu gribe virüsün yol açtığı bile tam olarak 1930 yılında tanımlanabilmiş ve ilk virüsün laboratuvar ortamında ayrıştırılabilmesi 1933 yılına kadar uzanmıştır. Korona virüs salgınında olduğu gibi bu pandemide de aşının ve bilinen bir tedavinin olmadığı ortamda salgını durdurmanın anahtarı önleyici tedbirlerin sıkı bir şekilde uygulanmasındaydı. Bu önlemlerin ne kadarının hangi ölçüde etkili olduğunu tam olarak ölçmek zor olsa da bugünün dünyasına çok sayıda değerli ders niteliğine sahip olmuştur. Sağlık eğitimi, izolasyon, hijyen, vakaların izlenmesi gibi stratejilerin grip türlerinin yayılmasını engelleme konusundaki etkileri söz konusu olan bu derslerin arasında yer almaktadır. Gribin dalgalar halinde neredeyse iki yıl devam etmesi ise bu önlemlerin zamanından önce gevşetilmesinin ağır maliyetini göstermektedir.

Congressional Budget Office (2005) tarafından yapılan bir araştırmada Amerika için pandeminin ekonomik sonuçları tahmin edilmiştir. Bu tahminlere göre en iyi ihtimalle Amerika'da \%0,1 ölüm oranı görülecektir. Daha kötümser bir tahmine göre ise bu oran \%2,5 seviyesine kadar çıkacaktır. Yine bu araştırmaya göre Amerika için GSYİH daralması en iyi ihtimalle \%1,5 olarak ve daha kötü bir ihtimalle de GSYH'nin \%5'i düzeyinde gerçekleşecektir

\section{21. Yüzyıl Salgını Olarak 2013-2016 Ebola Salgını}

Afrika'da 2013-2016 döneminde ortaya çıkan Ebola salgını sonucunda yaklaşık 11.300 kişi hayatını kaybetmiştir. Ebola salgınının Batı Afrika'daki ekonomik ve sosyal etkisine bakıldığında, ülke ekonomisinde 53 milyar ABD doları zarar görülmüş olup, 2015 yılı 
GSYİH'sı \%20 azalmıştır. Bu salgın bize, bir salgının sağlık üzerindeki etkisinin nispeten sınırlı olmasına karşılık, ekonomik sonuçlarının yıkıcı ve uzun süreli olabileceğini öğretmiştir. Örneğin, Liberya’nın genelinde ölüm oranları düşse bile, GSYİH seviyesi 2013-2014 döneminde \%8 düzeyine inmiştir (WHO, 2016). Virüsün halen geçerliliği kanıtlanmış bir tedavisi bulunmamakla birlikte, semptomları kontrol etmeye yönelik tedaviler uygulanmaktadir.

\section{Korona Virüs Salgınının Diğer Salgınlardan Farklı Olması}

Hayvanlardan insanlara mutasyon geçirerek bulaşan ve sonrasında insandan insana yayılan korona virüsler, son 20 yılda SARS ve MERS gibi salgınlarda sınır aşırı yayılarak hastalık ve ölümlere yol açmıştır. Son dönemde yaşadığımız korona virüs salgını sınır aşırı salgın hastalıkların dünya ölçeğinde ne denli hızlı bir biçimde yayılabileceğini kanıtlamaktadır ve hizla yayılmaya devam etmektedir.

Korona virüs salgınının yarattığı etkileri 2008 finansal krizi gibi diğer küresel krizlerle karşılaştırmak mümkün değildir. Zira Covid-19 küresel bir salgın olmasının yansıra düşük ve orta gelirli ülkelere odaklanmamıştır. Faiz oranları tarihsel süreçte görülen en düşük düzeydeki faiz oranlarıdır. Dünya ülkeleri birbiriyle daha bağlı ve entegredir. Mevcut kriz, tedarik zincirleri boyunca yayılma etkileri yaratmaktadır ve aynı zamanda eşanlı olarak ortaya çıkan bir arz ve talep şoku söz konusudur.

Ne yazık ki, Covid-19'un ekonomik etkileri sektörler ve ülkeler arasında ciddi derecede hissedilmektedir. Dünya genelinde ortaya çıkan etkilere baktığımızda Volkswagen ve Ferrari gibi otomobil üreticileri Avrupa'da üretimi askıya almış bulunmaktadır. Ulaşım, eğlence, perakende, otel ve restoranlar gibi ülke GSYH'sinin neredeyse dörtte birini oluşturan kilit sektörler ciddi düzeyde zarar etmiştir. Dow Jones 16 Mart 2020'de 2.977 puanlık düşüş yaşayarak bir günlük en kötü düşüşü kaydetmiştir. Paris, Madrid, Venedik ve Roma gibi turistik yerler terk edilmiş, ticari fuarlar ve etkinlikler iptal edilmiştir. Halka açık toplantılar ve spor karşılaşmaları iptal edilmiş olup, kara, deniz ve hava taşımacılığı seferleri Mayıs ayına kadar son bulmuştur. Çin'de milyonlarca insan işini kaybetmiş, Kanada'da yüzlerce sinema salonunun tamamı kapanmıştır.

Lüks mal üretimi yapan şirketler üretimi durdurmuş, İsviçre salgın sonrasında sadece vatandaşlarına, bölge sakinlerine ve taşıtlara kapılarını açmıştır. Covid-19'a ilişkin hala çok fazla belirsizlik ve soru işareti mevcuttur. Mevcut veriler, Covid-19'un SARS'den daha bulaşıc1 olduğunu göstermektedir. Diğer taraftan, Covid-19 SARS (\%10) ile karşılaştırıldığında çok 
daha düşük ölüm oranına (\%2-4 arasında) sahiptir ve her ikisinde de kuş gribinden (\%60) çok daha düşük ölüm oranı gerçekleşmiştir (Chou vd., 2004).

Pandemi en çok hizmet sektörünü etkilemiştir. Birçok ülke süresiz olarak kilitlenmiştir. İnsanlar evde çalışmaya ya da işe gitmemeye başlamıştır. Tüketicilerin ihtiyari harcamaları son bulmuştur. Avrupa'da insanlar toplu taşımayı tercih etmemekte ve restoranlar, alışveriş merkezleri, müzeler gibi kamusal alanlardan kaçınmaktadır. Dolayısıyla aslında bu durumdan tüm sektörler olumsuz yönde etkilenmektedir. Bununla birlikte, Covid-19'un etkileri ekonomi genelinde yer alan sektörlerde eşit ağırlıkta görülmemektedir. Bazı sektörler finansal olarak bu durumdan yararlanabilirken (hijyen ürünleri satan firmalar vb.) diğerleri iflas noktasına gelebilmektedir. Turistik yerler terk edilmekte, seyahatler ertelenmektedir. Çinli turistlerin dünyanın en büyük harcama yapan kesimi olduğu göz önüne alındığında seyahat ve turizmin GSYİH'ya olan toplam katkısının dünya genelinde ciddi oranda azaldığı dikkat çekmektedir. Kültür ve Turizm Bakanlığı'nın 2019 ve 2020 yıllarında yayınlamış olduğu raporlara göre 2019 yılı birinci çeyreğinde ülkemize gelen toplam ziyaretçi sayısı 6,8 milyon olmuştur. Bir önceki yıla göre toplam ziyaretçi sayısı \% 7 oranında artmıştır. Ancak, koronavirüsün seyahat ve turizm üzerinde yaratmış olduğu olumsuz etkiler sonucunda 2020 yılı birinci çeyreğinde ülkemize gelen toplam ziyaretçi sayısı 2019 yılına göre \%20,5 azalarak 5,5 milyon seviyesine gerilemiştir.

\section{a. Covid-19'u SARS ile Karşılaştırmak Olası Değildir}

2002 yılında Çin'in Guangdong eyaletinden Asya ülkelerine şiddetli akut solunum yolu sendromu (SARS) patlak vermiştir. 8.000'den fazla insan enfekte olmuş ve 900'den fazla insan hayatını kaybetmiştir (WHO, 2003). Dünya Bankası verilerine göre, SARS Çin'in 2003 yılı büyümesinde \%0,5 ile \%1'lik bir düşüşe yol açmıştır. Genel olarak SARS'ın küresel ekonomiye maliyetinin ise 54 milyar dolar olduğu tahmin edilmektedir (Lee and McKibbin, 2004).

Her ikisinin de korona virüs enfeksiyonları olmaları yönüyle tıbbi açıdan benzerlikler söz konusu olmasına rağmen, iki salgının ekonomik etkileri oldukça farklıdır. Dolayısıyla, SARS ile karşılaştırmalar düzgün ve dikkatli bir şekilde yapılmalıdır. Birincisi, Çin 2003 yılında dünya ekonomisinin \% 3'ünü temsil etmekte olup günümüzde bu oran \%16'nın üzerine çıkmış bulunmaktadır. Dolayısıyla, Çin'deki faaliyetlere yönelik herhangi bir şok, tüm dünyadaki pazarlarda, tüm farklı sektörlerde güçlü bir şekilde hissedilecektir. Diğer taraftan, Çin şu anda dünyanın en büyük ithalatçısı ve ihracatçısı konumundadır. Birçok farklı bireysel endüstride, 
Çin parçaların ana tedarikçisidir. Dolayısıyla, ara girdiler için Çin'e güvenen ülkeler (Apple, Nike vb) bu durumdan ciddi bir şekilde etkilenmektedir (Hai vd., 2004).

Çin aynı zamanda birçok endüstride küresel mal ve hizmetlerin ana alıcısıdır. Dünya Turizm Örgütü verilerine göre 2014 yılından bu yana Çin, uluslararası turizmin merkezi konumundadır. Bu durum, birçok ülkenin hizmet ihracatının büyük ölçüde Çinli tüketicilere bağlı olduğu anlamına gelmektedir. Aynı zamanda Dünya ekonomisi 15 yıl öncesine göre çok daha entegre olmuş durumdadır. Dolayısıyla, bir ülkede ortaya çıkabilecek ekonomik bozulmanın çok daha büyük yayılma etkileri mevcuttur.

Çin, 2019 yılında dünya GSYİH'nın yaklaşık \%40'ını temsil etmekteydi. 2003 yılında Çin'de ortaya çıkan \%1 oranındaki küçülme dünya genelinde hissedilmemişti ancak günümüz koşulları altında \%1 düzeyindeki küçülmenin dünya ekonomisi üzerinde çok daha büyük etkiler yaratacağı kuşku götürmez bir gerçektir (Roberts, 2020).

\section{b. 2020 Yılı İkinci Çeyreğinin Birinci Çeyrekten Daha Kötü Olması Beklentisi}

Ortaya çıkan son veriler, Çin'in GSYH'sinin ikinci çeyrekte düşeceğini göstermektedir. Çin küresel ekonominin yaklaşık \%16'sını temsil ettiğinden, bu durum tüm dünyayı olumsuz yönde etkileyecektir (OECD, 2020). Krizden önce, 2020 yılının ilk çeyreğinde Çin için yapılan tahmini GSYİH büyümesi \%6 idi. Bugün itibariyle küresel bir pandemi ile karşı karşıyayız. Ülkeler ortaya çıkan bu kriz sürecinde Çin'in uyguladığı politikaları, önlemleri ve uygulamaları (kilitlenmeler, hareket kısıtlamaları, dev karantina hastaneleri, halk sağlığı önlemleri, yaşlıların korunması vb.) yakından takip etmektedir. Birçok ülkede kamusal hayata kısıtlamalar getirilmeye başlanmıştır. Bu kapsamda okullar ve işyerleri kapanmış, seyahatler engellenmiştir. Bugün gelinen noktada çoğu batı ülkesi salgına yönelik olarak alınan önlemler ve uygulamalar açısından Çin'in oldukça gerisinde yer almaktadır. Bu nedenle, dünyadaki ülkelerin çoğunda ikinci çeyreğin ilk çeyreğe göre daha kötü olacağına kesin gözüyle bakılmaktadır.

Çin'in Covid-19'a yönelik olarak alınan önlemler ve uygulamalar açısından göstermiş olduğu başarının altında yatan birçok farklı faktör mevcuttur. Öncelikli olarak Çin hükümetinin krize hızlı müdahale etmesinin ve ilgili tüm kuruluşları bilgilendirip, uyumlu bir şekilde çalıştırmasının hastalığın önlenmesinde çok büyük etkisi olmuştur, halk salgın ve sonuçları konusunda çok iyi bilgilendirilmiştir. İnsanların işini kaybetme kaygısıyla evlerinden dışarı çıkacağını ve hastalıklarını saklayacaklarını tahmin eden hükümet, vatandaşlarına her türlü ekonomik desteği sağlamıştır. Böylece insanlar kendilerini güven altında hissetmişlerdir. Halka 
karşı şeffaf olmak, tüm verileri zamanında, eksiksiz paylaşmak halkın işbirliği arzusunu desteklemiştir. Çin hükümeti aldığı bu önlemlerin yanı sıra, teknoloji ve yapay zekayı doğru ve etkin kullanarak salgını durdurmuş ve geriletmiştir (WHO, 2020).

\section{c. Kriz Sonrası Farklı Sektörlerde Oluşan Farklı Sonuçlar}

Kriz sonrası tüm sektörler krizden olumlu ya da olumsuz yönde etkilenecektir. Olumlu diyoruz çünkü Covid-19'un etkileri sektörler üzerinde eşit olarak dağılmayacaktır. Daha önce söz edildiği gibi bir kısım sektörler (hijyenik ürünler ya da maske üreten firmalar vb) krizden fayda sağlarken diğerleri iflasın eşiğine gelebilecektir. Krizin en olumsuz ve yıpratıcı etkileri şüphesiz hizmet sektöründe görülecektir. Bugün hizmet sektöründe yer alan firmalar turistik yerlerin terk edilmesine, yolculukların iptal edilmesine, otel ve restoranların kapatılmasına bağlı olarak \%90'dan fazla faaliyet azalmasıyla karşı karşıyadır (Morris and Karmin, 2020).

Ülkelerin kendine özgü kültür ve yapıları dolayısıyla turizme verilen önem de ülkeler arasında farklılaşmaktadır. Dünya Seyahat ve Turizm Konseyi verilerine göre turizme verilen önem açısından dünya genelinde ilk 10 sırada yer alan ülkeler sırasıyla; Yunanistan, Portekiz, Meksika, İspanya, Avusturalya, İtalya, Çin, Almanya, Amerika ve İsviçre'dir. Seyahatteki ciddi kısıtlamalar birçok dünya ülkesinde turizmi önemli ölçüde etkilemiştir. Yunanistan, Portekiz, Meksika ve İspanya gibi turizme oldukça fazla bağımlı olan ülkeler (GSYİH'nin \%15'inden fazlası) krizden bu anlamda daha fazla etkilenmişlerdir (Roberts, 2020). Pandemi sonrası günlük olarak kullandığımız hizmetlerin birçoğu artık işlem görmez ve tedarik edilemez hale gelmiştir. Bu durum ekonomik açıdan ciddi bir olumsuz etki yaratmıştır. Örneğin insanlar küresel çapta diş hekimindeki randevularını iptal ettirmeye, saç kesimlerini ertelemeye, yemeği dışarıda yememeye ya da satış planlarını askıya almaya başlamışlardır. Dolayısıyla hizmet odaklı ekonomilerde güçlü bir ekonomik bozulma ortaya çıkmıştır. Hizmet sektöründe kaybedilen gelirin çok büyük bir kısmının asla geri dönmeyeceği göz önüne alındığında durumun ne kadar ciddi olduğu daha iyi anlaşılmaktadır. Şöyle ki; krizin geçici olduğu, bittiğinde hala bir işinizin ve mevcut gelirinizin olduğu varsayımı altında dahi bir cep telefonu veya televizyon satın almayı düşünüyorsanız, pandemi nedeniyle bu ürünü almayı erteleyip daha başka bir zaman zarfında satın alacaksınız. Bir başka örnekle kriz boyunca yemeği dışarda yemediniz, çok büyük bir ihtimalle kriz sona erdikten hemen sonra akşam yemeğini her gün dışarda yemeğe başlamayacaksınız veya sık sık kuaför ya da berbere de gitmeyeceksiniz. Dolayısıyla, kriz döneminde hizmet sektöründe ortaya çıkan maliyet kaybı kriz sonrasında da telafi edilemeyecek. 


\section{d. Covid-19'un Tedarik Zincirleri Üzerindeki Etkileri}

Tedarik zinciri ağları, Covid-19'un küresel ekonomiyi olumsuz yönde etkilediği bir başka kanaldır. Covid-19 sonrası küresel tedarikin işleyişi bozulmuş olup, bu durum tedarikçi ağlarında farklı seviyelerde yayılma etkileri yaratmıştır. Otomotiv şirketleri, birçok farklı endüstriyel sektörde olduğu gibi, parça eksikliğinden dolayı üretimlerini durdurmuştur. İsviçre saatleri gibi lüks mallarda bile, üreticiler aksayan parça tedariği ile karşı karşıya kalmıştır. Tedarik zincirlerindeki aksama, imalat şirketleri için iş maliyetini artırmıştır. Ürünlerinin neredeyse \%70'ini Çin'den tedarik eden üreticiler iflasın eşiğine gelmiştir. Çin'deki fabrikalar kapandıkça ve ulaşım rotaları çöktükçe, dünya genelinde ürünlerin pazara sunulması giderek zorlaşmıştır. ABD'deki şirketlerin \%75'i tedarik zincirlerinde aksamalar olduğunu bildirmiştir. Birçok ABD şirketi teslim sürelerini rutinin iki katına çıkarmıştır (Taylor and Schwartz, 2020). Ayrıca pandemi sonrası dünya genelinde hammadde ve nihai ürün sıkıntısı yaşanmıştır. Hava ve deniz taşımacılığı seçeneklerinin yetersizliği ile problemler daha da artmıştır. Virüsün dünyaya yayılması aynı zamanda Çin ürünlerine olan talebi daha çok azaltan küresel bir durgunluk korkusu yaratmıştır. Birçok farklı ülke ortaya çıkan yüksek maliyetlere bağlı olarak risk azaltma stratejileri uygulamaya başlamıştır.

\section{e. Covid-19’un Çin Ekonomisi Üzerindeki Etkileri}

Covid-19 sonrası Çin ekonomisinin normale dönmesi uzun zaman alacaktır. Yayınlanan son verilere göre Çin'de sanayi üretimi 2020 yılının ilk iki ayında \%13,5’ten fazla azalmıştır. Benzer şekilde, duran varlıklara yapılan yatırımlar geçen yıla göre \%25 azalmıştır. Çinli tüketiciler, yetkililerinin tavsiyelerini dikkate alarak alışveriş merkezlerinden, restoranlardan ve sinema salonlarından uzaklaşmışlardır. Bunun bir sonucu olarak perakende satışlar \%20 oranında düşmüştür (Lo, 2020).

16 Mart 2020'de yayınlanan veriler, Çin'de 5 milyon kişinin Ocak ve Şubat aylarında işlerini kaybettiğini göstermiştir. Ancak bu rakamın 9 milyondan fazla olacağı yönünde beklentiler mevcuttur. Diğer taraftan Çin'de altyapı yatırımları da bir önceki yıla oranla \%30 düşmüştür. Çin'in beş yıllık kalkınma planları da sona ermiştir. Kalkınma planlarında yer alan 2010 yılından 2020 yılına kadar Çin ekonomisinin büyüklüğünü iki katına çıkarma hedefi gerçekleştirilememiştir. Bu hedefin gerçekleşmesi için 2020 yılında Çin’in \%6'nın üzerinde bir büyüme performansı sergilemesi gerekmekteydi (WHO, 2016). 
Çin'de hükümet ekonomik teşviklerle istikrarlı büyüme beklentilerini korumaya çalışmaktadır. Ancak, işletmelerin sermaye giderleri ve tüketici harcamaları hedef GSYİH seviyesini yükseltmede zorluklar yaratabilmektedir. Gerçekten de, Çin'de Covid-19 salgınından üç ay sonra ekonomi iyileşmeye başlasa bile, işletmeler hala normal kapasitelerinin altında çalışmaktadır. Virüsün küresel çapta yayılmasına bağlı olarak küresel talep azalmakta ve Çin ürünlerine olan talep de hızla düşmektedir.

\section{f. Covid-19'un Hisse Senedi Piyasaları ve Bankalar Üzerinde Yaratacă̆ı Etkiler Üzerine Temel Varsayımlar}

2020 Mart ayı itibarıyla borsalar çökmüştür. Dünyadaki çoğu hisse senedi endeksi bir günlük en büyük düşüşlerini rekor seviyede kaydetmiştir. Birkaç tanınmış şirket hisse fiyatlarının birkaç gün içinde \%80'den fazla düştügünü belirtmiştir. Küresel borsaların 2020'deki performanslarına bakıldığında en kötü performans gösteren ilk 10 hisse senedi piyasasının Japonya, Amerika, Portekiz, Hollanda, Almanya, İspanya ve Ukrayna'da yer aldığ1 görülmektedir (Esposito, 2020). Hisse senedi piyasalarında ortaya çıkan oynaklığın tarihsel süreçte Pandemi sonrası zirve yaptığı görülmektedir. Hisse senedi piyasalarında ima edilen oynaklık genellikle mevcut ortamın ne kadar riskli olduğunun ve geleceğin ne kadar belirsiz olduğunun bir göstergesi olarak kullanılır (Bkz. Korku Endeksi).

Tarihsel süreçte ortaya çıkan tüm krizler diğer olaylar tarafından tetiklenmiştir (borç krizi, bütçe açığı, konut kredisi balonu, bankacılık krizi, ticari çöküş, siyasi olaylar, savaşlar vb.). Geçmiş krizlerin çoğunda, merkez bankaları daha fazla zarar görmemek için çeşitli politikalar uygulamışlardır. Daha önce görülen krizlerin hiçbirinde, faiz oranlarının başlangıç noktası bu derece düşük (bazı durumlarda negatif) olmamıştır. Bu durum piyasalar üzerinde etkili olacak bir politika uygulamasının imkânsız olduğu konusunda endişe yaratmaktadır.

Belirsizliğin oldukça yüksek seviyede olduğu bu ortamda Covid-19 krizinin ekonomik etkilerini tam olarak tahmin etmek oldukça güçtür. Söz edildiği gibi, doğrudan kullanabileceğimiz hiçbir tarihsel kriter yoktur. Daha önce böyle bir kriz yaşanmamıştır. Merkez bankalarının sıfır veya negatif faiz oranları ile savaştığı, arz ve talebin aynı anda etkilendiği bir ortam mevcut olup kriz aynı zamanda sağlığ 1 da ciddi oranda etkilemektedir. Dolayısıyla, ekonomi üzerinde temel varsayımlarda bulunabilmek için mevcut verileri mümkün olan en iyi şekilde kullanmamız gerekmektedir. 
Karantina süresince tüketim, üretim, yatırım ve perakende satışlarda oluşan küresel çaptaki düşme eğilimi e-ticaretin daha az geliştiği ülkelerde tüketim üzerinde daha fazla tahribatın oluşmasına yol açmıştır.

Durgunluğun ekonomik maliyeti dünya genelinde aynı değildir. Ülkelerin farklı endüstriyel yapıları göz önüne alındığında, etkiler dünya çapında farklı hissedilmektedir. Daha büyük turizm sektörüne sahip olan ülkeler (GSYH’nin yüzdesi olarak), daha endüstriyel odaklı ülkelere göre daha ciddi şekilde etkilenecektir. Diğer taraftan ihracata daha fazla bağımlı olan ülkeler orantısız olarak daha fazla zarar görecektir.

Covid-19'un doğrudan ve dolaylı etkilerinden söz ederken küresel düzeyde oluşan sağlık maliyetlerini net bir şekilde dikkate almak oldukça zor olduğu için krizin yaratmış olduğu ekonomik maliyeti tam olarak hesaplamak mümkün değildir. Ülkelerin hemen hemen tamamında işgücü arzında şoklar meydana gelmiş olup enfeksiyonlara bağlı ölüm oranlarına ve enfekte olanların işe dönüşündeki gecikmelere göre bu durum değişecektir. Diğer taraftan Finansal sektörde önemli bir aksaklık meydana gelirse, bu açıkça finansal bağımlılı̆̆ daha yüksek olan firmaları daha çok etkileyecektir.

\section{Tablo 1: Covid-19’un Ekonomik Etkileri (GSYİH'nın Yüzdesi Olarak)}

\begin{tabular}{|c|c|}
\hline ÜLKELER & EKONOMIK ETKI (\%) \\
\hline Brezilya & -3.0 \\
\hline Kanada & -2.9 \\
\hline Çin & -3.2 \\
\hline Fransa & -3.2 \\
\hline Almanya & -3.6 \\
\hline Yunanistan & -4.6 \\
\hline İtalya & -3.7 \\
\hline Japonya & -2.7 \\
\hline Portekiz & -4.5 \\
\hline İspanya & -3.9 \\
\hline Birleşik Krallık & -3.4 \\
\hline Türkiye & -3.2 \\
\hline Amerika & -2.9 \\
\hline
\end{tabular}

Kaynak: OECD (2020), World Bank Group (2019)

Tablo 1, her bir ülke için GSYİH yüzdesi olarak ifade edilen, Covid-19 krizinin yarattığ1 ekonomik şoku göstermektedir. Birçok farklı varsayım altında krizin genel ekonomik maliyeti 
tahmin edilmektedir. Tahminler virüsün ortaya çıktığı tarihten itibaren ilk 1,5 aylık süreci kapsamaktadır.

Tablo 1'e göre, krizin Amerika'da GSYH'nin yaklaşı \%3 oranında azalmasına yol açması beklenmekte olup, incelenen tüm ülkelerin GSYİH‘lerinin \%3,5 oranında küçülmesi ön görülmektedir. Beklentide bulunurken farklı ülkelerdeki farklı GSYİH bileşimleri dikkate alınmaktadır. Örneğin turizmin ağırlığı arttıkça krizin etkisi de artmaktadır. Bu nedenle veriler Yunanistan, İtalya, Portekiz ve İspanya'nın bu krizden en fazla etkilenen ülkeler arasında yer alacağını göstermektedir (Esposito, 2020).

\section{Tablo 2: Farklı Ülkelerde Tahmini GSYİH Büyümesi}

\begin{tabular}{|c|c|}
\hline ÜLKELER & TAHMINI GSYIH BÜYÜMESI (\%) \\
\hline Brezilya & $-0,9$ \\
\hline Kanada & $-1,2$ \\
\hline Çin & 2,6 \\
\hline Fransa & $-2,0$ \\
\hline Almanya & $-2,4$ \\
\hline Yunanistan & $-2,4$ \\
\hline İtalya & $-3,2$ \\
\hline Japonya & $-2,3$ \\
\hline Portekiz & $-2,9$ \\
\hline İspanya & $-2,1$ \\
\hline Birleşik Krallik & $-2,0$ \\
\hline Türkiye & $-1,8$ \\
\hline Amerika & $-0,8$ \\
\hline
\end{tabular}

Kaynak: IMF (2019), OECD (2020)

Tablo 2'de her ülke için beklenen GSYİH büyümesi hesaplanırken, kriz öncesi beklenen GSYİH büyümesi (IMF 2019 sonu tahminleri) ve Covid-19 krizinin yukarıdaki tabloda belirtilen ekonomik maliyetleri (1,5 aylık tahminler) dikkate alınmıştır. Örneğin, Fransa'nın 2020 büyüme hedefi \%1,2 olarak belirlenmiştir. Tablo 1'deki krizin ekonomik etkisi (\% -3.2) göz önüne alındığında, Fransız GSYH’sinin tahmini büyüme oranı \%-2 olarak hesaplanmıştır. Amerika'nın bu süreçte \%-0.8 GSYİH büyümesi ile durgunluğa girmesi beklenmektedir. Korona virüs nedeniyle oluşan ekonomik gerilemenin Amerika tarihindeki en uzun vadeli genişlemeye son vermesi kaçınılmaz görünmektedir (Fernandes, 2020).

Mevcut krizin etkisi diğer krizlerde olduğu gibi dünya genelinde farklı seviyede gerçekleşecektir. Çin'de GSYH'nin \%3’ten daha az oranda büyümesi tahmin edilmektedir 
(Kriz öncesi bu tahmin \%6 düzeyindeydi). Diğer taraftan, Avrupa ülkelerinin çoğunda ciddi durgunlukların yaşanması beklenmektedir. Kriz öncesi Avrupa ülkelerinin zaten fazla büyümesi beklenmiyordu. Kriz sonrası GSYİH'lerinin \%2 ila \%3 seviyesinde küçülmesi öngörülmektedir. Önceki durgunluklardan yola çıkarak, GSYH'de oluşan bu büyüklükte bir düşüşün işsizliği önemli ölçüde artıracağını söyleyebiliriz. Genel olarak, bu durum, bu ülkeler için, 2020'de \%-1.7'lik bir ortalama negatif büyümeye yol açmakta olup, bu oran 2019'da görülen \%3'e yakın büyüme oranının oldukça altında kalmaktadır (Fan vd., 2018).

Covid-19 ile ilgili alınan önlemler Haziran 2020'nin sonuna kadar devam ederse, ABD GSYH'sinin neredeyse \%4 seviyesine kadar düşmesi öngörülmektedir. Ortalama olarak, krizin devam ettiği her ayın küresel GSYH'de \%2 ile \%2,5 oranında küçülmeye yol açacağı tahmin edilmektedir. Eğer kriz temmuz ayı ortasına kadar devam ederse en zorlu ekonomik koşullarla karşılaşmak olası olacaktır. Bu durumda küresel çapta GSYH'deki ortalama düşüş \%8'e yakın olacaktır. Turizme yüksek oranda bağımlı olan ülkeler daha fazla etkilenecek ve GSYH'deki azalma, bazı durumlarda \%10'dan daha yüksek olabilecektir (Dean, 2020).

Tablo 3: Seçilmiş Ülkelerde Üretim Maliyetlerinde Ortaya Çıkan Şoklar

\begin{tabular}{|c|l|l|l|l|l|l|}
\hline ÜLKELER & ENERJi & MADENCiLIIK & TARIM & $\begin{array}{l}\text { DAYANIKLI } \\
\text { IMALAT }\end{array}$ & $\begin{array}{l}\text { DAYANIKSIZ } \\
\text { IMALAT }\end{array}$ & HİZMET \\
\hline Arjantin & 0.37 & 0.24 & 0.37 & 0.35 & 0.40 & 0.38 \\
\hline Avustralya & 0.43 & 0.43 & 0.42 & 0.39 & 0.41 & 0.45 \\
\hline Brezilya & 0.44 & 0.46 & 0.44 & 0.42 & 0.45 & 0.44 \\
\hline Kanada & 0.44 & 0.37 & 0.42 & 0.40 & 0.41 & 0.44 \\
\hline Çin & 0.50 & 0.50 & 0.50 & 0.50 & 0.50 & 0.50 \\
\hline Fransa & 0.38 & 0.31 & 0.36 & 0.40 & 0.42 & 0.46 \\
\hline Almanya & 0.43 & 0.37 & 0.40 & 0.45 & 0.45 & 0.47 \\
\hline Hindistan & 0.47 & 0.33 & 0.47 & 0.42 & 0.45 & 0.43 \\
\hline Endonezya & 0.37 & 0.33 & 0.31 & 0.36 & 0.40 & 0.38 \\
\hline İtalya & 0.36 & 0.33 & 0.38 & 0.42 & 0.44 & 0.46 \\
\hline Japonya & 0.45 & 0.40 & 0.45 & 0.47 & 0.47 & 0.49 \\
\hline Meksika & 0.41 & 0.38 & 0.39 & 0.42 & 0.42 & 0.41 \\
\hline Kore & 0.39 & 0.30 & 0.37 & 0.43 & 0.42 & 0.43 \\
\hline Rusya & 0.54 & 0.37 & 0.43 & 0.41 & 0.42 & 0.45 \\
\hline Suudi Arabistan & 0.32 & 0.25 & 0.29 & 0.29 & 0.25 & 0.35 \\
\hline Güney Afrika & 0.40 & 0.35 & 0.39 & 0.41 & 0.43 & 0.38 \\
\hline Türkiye & 0.37 & 0.36 & 0.39 & 0.39 & 0.42 & 0.42 \\
\hline Birleşik Krallık & 0.39 & 0.37 & 0.39 & 0.39 & 0.42 & 0.46 \\
\hline Amerika & 0.53 & 0.40 & 0.51 & 0.50 & 0.51 & 0.53 \\
\hline Kayna McKibbin & & & & \\
\hline
\end{tabular}

Kaynak: McKibbin and Fernando (2020) 
McKibbin and Fernando (2020) çalışmalarında Covid-19 sonrası farklı ülkelere yönelik olarak çeşitli sektörlerde üretim maliyetlerinde ortaya çıkan şokları yüzdesel olarak araştırmışlardır. Covid-19 krizi sonrası işgücü girdilerinde oluşan yüksek maliyetlerin yanısıra, ticaret, kara ve hava taşımacılığı ve deniz taşımacılığı gibi diğer girdilerin de salgından önemli ölçüde etkilendiği tespit edilmiştir. Dolayısıyla çalışmada her bir sektörün Çin ekonomisi içindeki payları hesaplanmış ve GSYİH üzerindeki etkileri de dikkate alınmıştır. SARS salgını sırasında Çin'de yer alan üretim sektörlerinin üretim maliyetlerindeki artış yüzdeleri belirli senaryolar altında belirlenmiş ve işgücünde ortaya çıkan değişimlerle eşleşecek şekilde ölçeklendirilmiştir. Tablo 3, ülkelerin her birindeki üretim maliyetinde oluşan şokları içermektedir.

\section{Sonuç Yerine}

Covid-19 krizi tüm dünyada hızla yayılmıştır. Suudi Arabistan ve Rusya arasındaki petrol savaşı ve seyahat engelleriyle birleştiğinde, bu durum borsaları 1987'den bu yana en kötü duruma getirmiştir. Bugün dünya tamamen yeni bir krizle karşı karşıya bulunmaktadır. Bu şartlar altında küresel durgunluk kaçınılmaz olarak görünmektedir. Ancak düşüşün ne kadar derin ve uzun olacağı, Covid-19'un yayılmasını önlemek için hükümet tarafından alınan önlemlerin ve uygulanan politikaların başarısına, KOBİ'lerde likidite sorunlarının ne ölçüde hafifletilebileceğine, mali açıdan sıkıntı çeken aileleri desteklemek ve işlerini güvence altına almak için uygulanacak olan hükümet politikalarının etkilerine bağlıdır. Krizin derinliği aynı zamanda şirketlerin krize karşı verecekleri tepkiye ve mevcut kilitlenmelerin ne kadar süreceğine de bağlıdır.

Merkez bankaları kriz sürecinde farklı stratejiler izlemektedirler. Mart ayında Amerika Merkez Bankası, İngiltere Merkez Bankası ve merkez bankalarının birçoğu faiz oranlarını aşağıya çekmiştir. Dünya genelinde hükümetler likidite artırma programlarını duyurmak için acele etmektedirler. Bununla birlikte, hükümet ve merkez bankalarına piyasaları sakinleştirmek ve ekonomiyi iyileştirmek için çok fazla görev düşmektedir.

Covid-19 krizinin ekonomik maliyetleri dünya genelinde yer alan ülkeler için aynı değildir. Küresel çapta zaten mevcut olan işsizlik daha da artmıştır. Daha önce yaşanan krizlerde olduğu gibi bu krizde de daha genç ve daha az eğitimli işçilerin işlerini kaybetme olasılıkları daha yüksek olacaktır. Covid-19'un ekonomik etkilerini net bir biçimde ortaya koymak maalesef bu şartlar altında mümkün değildir. Bu, pandeminin gelecek zaman zarfındaki ilerlemesinin hangi hızda olacağına, ciddiyetinin ne olacağına, ülkelerin vereceği tepkilere, hükümetlerin uygulayacakları politikalara ve önlemlere bağlı olarak değişecektir. Eğer, Covid-19'un ortaya 
çıkardığı kriz yaz sonuna kadar devam ederse, küresel ekonomi son iki yüzyılda görülen en büyük tehditle karşı karşıya kalacaktır.

Bilimin ve teknolojinin ön plana çıktığı 21. Yüzyılda korona virüs, tarihsel süreçte bir salgın hastalık olarak yeniden ortaya çıkmıştır. Bakteri ve virüsten doğan bu tarz hastalıkların belirli dönemlerde sık sık görülmesi aslında doğal dengeyi göz ardı eden, daha çok gelir ve rant elde etme hırsının yarattığı negatif dışsallıklardan kaynaklanmaktadır. Dolayısıyla, Covid-19 salgını sosyoekonomik hayat başta olmak üzere sağlık, eğitim ve sosyokültürel alanlarda hızlı bir değişime yol açacak ve bireylerin yaşam tarzlarının farklılaşmasına neden olacaktır. $\mathrm{Bu}$ bağlamda, henüz şans varken bilimden sanata, üretimden tüketime her alanda süreklilik teşkil eden çözümler yaratılmaya çalışılmalı, Türkiye'nin ihtiyacı olan siyasal, sosyal ve ekonomik reformlar uygulanmalıdır. 


\section{Kaynakça}

Chou, N. F., et al., 2004. Potential Impacts of the SARS Outbreak on Taiwan's Economy. Asian Economic Papers 3(1), 84-112.

Congressional Budget Office, 2005. A Potential Influenza Pandemic: Possible Macroeconomic Effects and Policy Issues. CBO Washington DC.

Crosby, A. W., 2003. America's Forgotten Pandemic: The Influenza of 1918. Cambridge University Press.

Esposito, A., 2020. The Worst Hit Equity Sectors in 2020. Morningstar. Available at_ https://www.morningstar.co.uk/uk/news/200469/the-worst-hit-equity-sectors-in2020.aspx. [Accessed: 19 March 2020].

Fan V.Y., et al., 2018. Pandemic risk: how large are the expected losses?, Bulletin of the World Health Organization.

Fernandes, N., 2020. Economic Effects of Coronavirus Outbreak (COVID-19) on the World Economy', March 2020.

Hai, W., et al., 2004. The Short-Term Impact of SARS on the Chinese Economy. Asian Economic Papers 3(1), 57-61.

IMF Working Paper, 2019. The Economic Consequences of Covid-19 in the World.. W/02/38, 41-95.

Lee, J-W and McKibbin, W., 2004. Globalization and Disease: The Case of SARS. Asian Economic Papers Vol. 3 No. 1, pp. 113-131.

Lo, K., 2020. Coronavirus: China says over 90 per cent of state firms back in business after manufacturing index hits all-time low". South China Morning Post. Available at: https://www.scmp.com/economy/china-economy/article/3053073/coronavirus-chinasays-90-cent-state-firms-back-business. [Accessed: 20 March 2020]

McKibbin, W. and Fernando, R., 2020. The Global Macroeconomic Impacts of COVID-19: Seven Scenarios, pp. 14-16.

Morris, K. and Karmin, C., 2020. Hotels Turn to Layoffs, Room Rate Cuts as Business Staggers. The Wall Street Journal. Available at: https://www.wsj.com/articles/hotelsturn-to-layoffs-room-rate-cuts-as-business-staggers-11584108223. [Accessed: 14 March 2020]. 
OECD, 2020. Global economy faces gravest threat since the crisis as coronavirus spreads. Available at: http://www.oecd.org/economy/global-economy-faces-gravest-threatsince-the-crisis-as-coronavirus-spreads.htm. [Accessed: 10 March 2020].

Roberts, C., 2020. Europe Resorts to Unprecedented Restrictions on Public Life. CNN Money Switzerland. Available at: https://www.cnnmoney.ch/shows/big-picture/videos/europeresorts-unprecedented-restrictions-public-life. [Accessed: 15 March 2020].

Taylor, D. and Schwartz, J., 2020. Volkswagen Suspends Production as Coronavirus Hits Sales. Reuters. Available at: https://www.reuters.com/article/us-volkswagen-results2019/volkswagen-suspends-production-as-coronavirus-hits-sales-idUSKBN2140OF. [Accessed: 15 March 2020].

T.C. Kültür ve Turizm Bakanlığı, 2019. Ocak-Mart Turizm İstatistikleri.

T.C. Kültür ve Turizm Bakanlığ1, 2020. Ocak-Mart Turizm İstatistikleri.

World Bank Group, 2019. Pandemic Preparedness Financing - Status update. World Bank, September 2019.

World Health Organization, 2003. A World at Risk. Annual Report on Global Preparedness for Health Emergencies. Geneva: World Health Organization.

World Health Organization, 2016. Ebola situation report - 16 March 2016. Geneva: Available from:

http://apps.who.int/iris/bitstream/10665/204629/1/ebolasitrep_16Mar2016_eng.pdf?ua $=1$ [cited 2016 Apr 2].

World Health Organization, 2020. Coronavirus Disease (Covid-19), Situation Report-142, 10 June 2020. 